\title{
Effect of Inflation, BI Rate, and Rupiah Exchange Rate Against Stock Return Case Study on Property and Real Estate Company
}

\author{
Sutarjo $^{1}$, Wahyuni Murti², Sugiyanto Saleh ${ }^{3}$ \\ \{sutarjo@unis.ac.id ${ }^{1}$, murti_why@yahoo.com², Sugiyantosaleh17@gmail.com³ ${ }^{3}$. \\ Universitas Borobudur, Jakarta, Indonesia ${ }^{1,2,3}$
}

\begin{abstract}
The point of this examination is to sort out how expansion, the BI Rate, and the Rupiah Exchange Rate all influence stock returns. The accentuation of this examination is on property and land endeavors recorded on the Indonesia Stock Exchange from 2016 to 2018. On the Stock Market (IDX) website, you can get data. The Statistical Product and Service Solution was used in conjunction with a quantitative methodology. The sample is obtained by the use of purposeful sampling. According to the findings of this study with a value of Fcount 2.255 and Ftable of 2.900, Stock returns are unaffected on inflation, the BI Rate, or the Rupiah Exchange Rate. The coefficient of determination has an impact on inflation, as well as other variables. The Rupiah Exchange Rate and the BI Rate drive the $9.7 \%$ stock return, while some other variables and the predictive value parameter impact the rest.
\end{abstract}

Keywords: Inflation; BI Rate; Rupiah Exchange Rate; Stock Return

\section{Introduction}

Investment in recent years has become a trend that is often talked about by many people. The placement of a number of funds at this time with the hopes of generating rewards in the future is known as investment. In increasing employee productivity. The development of the property sector will of course attract investors due to rising land and building prices which tend to rise. In developed and developing countries the property business is experiencing rapid growth. Shares of property companies in Indonesia are starting to be in demand, this has also caused many companies to list on the Indonesia Stock Exchange so that their company shares can be bought by investors.

Table 1. Index Sector Property 2014-2018

\begin{tabular}{|c|c|}
\hline Tahun & Indeks Properti \\
\hline 2018 & $3,11 \%$ \\
\hline 2017 & $3,68 \%$ \\
\hline 2016 & $4,69 \%$ \\
\hline 2015 & $4,11 \%$ \\
\hline 2014 & $5 \%$ \\
\hline
\end{tabular}

Sumber : Badan Pusat Statistik (www.bps.go.id)(2019). 
Seen from the table 1 above, sales in the property sector continued to decline from $2014-$ 2018. The decline in 2015 was $4.11 \%$ and continued to decline in 2018 by $3.11 \%$.

Table 2. Return index stock property $2016-2018$

\begin{tabular}{|c|c|c|c|}
\hline \multirow{2}{*}{ Date } & \multicolumn{3}{|c|}{ Return Indeks Saham Properti\% } \\
\cline { 2 - 4 } & $\mathbf{2 0 1 6}$ & $\mathbf{2 0 1 7}$ & $\mathbf{2 0 1 8}$ \\
\hline Jan & $0,003 \%$ & $0,072 \%$ & $0,085 \%$ \\
\hline Feb & $0,003 \%$ & $-0,086 \%$ & $0,013 \%$ \\
\hline Mar & $0,037 \%$ & $-0,012 \%$ & $-0,076 \%$ \\
\hline April & $0,016 \%$ & $-0,009 \%$ & $-0,052 \%$ \\
\hline Mei & $0,011 \%$ & $-0,026 \%$ & $-0,018 \%$ \\
\hline Jun & $0,077 \%$ & $0,003 \%$ & $-0,071 \%$ \\
\hline Jul & $0,029 \%$ & $0,003 \%$ & $0,022 \%$ \\
\hline Aug & $0,011 \%$ & $0,032 \%$ & $0,009 \%$ \\
\hline Sept & $-0,003 \%$ & $-0,021 \%$ & $-0,057 \%$ \\
\hline Okt & $0,004 \%$ & $0,018 \%$ & $-0,045 \%$ \\
\hline Nov & $-0,057 \%$ & $-0,038 \%$ & $0,091 \%$ \\
\hline Des & $-0,027 \%$ & $0,011 \%$ & $0,016 \%$ \\
\hline
\end{tabular}

In table 2 it can be seen that the movement of property sector stock returns during 20162018 experienced an up and down movement for each month in that period. Seeing the fact that there is no certainty about the return that will be obtained by investors when investing in stocks, there needs to be consideration for investors to make investment decisions. In table 3 , inflation that occurred in Indonesia in January - December 2016 was 3.02\% compared to the previous year in 2015 of $3.35 \%$. The low amount of inflation is due to the decline in people's purchasing power in the fourth quarter of 2016 (Central Bureau of Statistics, 2018).

Table 3. Data Inflasi 2015-2018

\begin{tabular}{|c|c|c|}
\hline Tahun & Target Inflasi & Inflasi Aktual \\
\hline 2015 & $4 \pm 1 \%$ & $3,35 \%$ \\
\hline 2016 & $4 \pm 1 \%$ & $3,02 \%$ \\
\hline 2017 & $4 \pm 1 \%$ & $3,61 \%$ \\
\hline 2018 & $3,5 \pm 1 \%$ & $3,13 \%$ \\
\hline \multicolumn{2}{|c|}{ Sumber : (Bank Indonesia, 2018) (Data diolah) }
\end{tabular}

Inflation rate in Indonesia is also influenced by interest rate policy. The BI Rate is a policy used by Bank Indonesia to determine the benchmark interest rate see table 4 .

Table 4. BRI rate growth 2014-2018

\begin{tabular}{|c|c|}
\hline Tanggal & BI Rate \\
\hline 2014 & $7,75 \%$ \\
\hline 2015 & $7,50 \%$ \\
\hline 2016 & $4,75 \%$ \\
\hline 2017 & $4,25 \%$ \\
\hline 2018 & $6 \%$ \\
\hline
\end{tabular}

Sumber : (Badan Pusat Statistik, 2018) (www.bps.go.id) 
Bank Indonesia decided to increase the interest rate by 25 basis points (bps) to the level of $5.75 \%$ in September 2018. This was due to the movement of various indicators such as inflation rate, trade balance, and also economic growth that occurred throughout the year in Indonesia, see table 5.

Table 5. Rupiah exchange rate data 2016-2018

\begin{tabular}{|c|r|r|r|}
\hline \multicolumn{5}{|c|}{ Data Nilai Tukar Rupiah } \\
\hline Date & $\mathbf{2 0 1 6}$ & $\mathbf{2 0 1 7}$ & $\mathbf{2 0 1 8}$ \\
\hline Jan & $13,719.00$ & $13,410.00$ & $13,480.00$ \\
\hline Feb & $13,462.00$ & $13,414.00$ & $13,776.00$ \\
\hline Mar & $13,342.00$ & $13,388.00$ & $13,825.00$ \\
\hline Apr & $13,270.00$ & $13,394.00$ & $13,946.00$ \\
\hline Mei & $13,683.00$ & $13,388.00$ & $14,021.00$ \\
\hline Jun & $13,246.00$ & $13,386.00$ & $14,476.00$ \\
\hline Jul & $13,159.00$ & $13,390.00$ & $14,485.00$ \\
\hline Aug & $13,367.00$ & $13,418.00$ & $14,785.00$ \\
\hline Sept & $13,063.00$ & $13,559.00$ & $15,004.00$ \\
\hline Okt & $13,116.00$ & $13,640.00$ & $15,303.00$ \\
\hline Nov & $13,631.00$ & $13,582.00$ & $14,411.00$ \\
\hline Des & $13,503.00$ & $13,616.00$ & $14,553.00$ \\
\hline \multicolumn{4}{|c|}{ Sumber : www.bi.20.id (Data Diolah) } \\
\hline
\end{tabular}

\section{Methodology}

The research method is a way to get a solution to all the problems posed [1]. A research in which there is a need for a theory to help methods that are relevant to the research problem, considering that not every problem studied is related to the ability of the researcher. So, it is necessary to have an appropriate research method to solve the research problem. The examination technique utilized is quantitative exploration, the data collected from a sample of the research population is evaluated and interpreted according to the statistical method used.

\subsection{Population}

According to Sugiyono, a researcher chooses to study and draw conclusions from a population, which is a generalized region made up of objects/subjects with particular quantities and features [1]. The 74 organizations in the Property and Real Estate industry that were recorded on the Indonesia Stock Exchange shaped the review's populace. Somewhere in the range of 2016 and 2018.

\subsection{Sample}

The sample is a representation of the population's size and features. As a result, the population sample must be properly representative (representing) the inspecting method utilized in this review, which is purposive testing, which is an information gathering strategy that decides specific measures and [1]. The stock file returns of property organizations recorded on the Indonesia Stock Exchange from 2016 to 2018 are the example rules to be utilized. 


\section{Results and Discussion}

\subsection{Classic assumption test}

a) Normality Test

The normality test determines if the regression model, confounding factors, and residuals have a normal distribution. The $\mathrm{t}$ and $\mathrm{F}$ tests are well-known for assuming a normal distribution for the residual value. The statistical test for a small sample size is faulty if this assumption is violated. To see if the data was regularly distributed, the Kolomogorov-Smirnov Test was performed. It is regularly distributed if the residual has a significant value greater than 0.05 .

b) Multicollinearity Test

According to Gujarati, the multicollinearity test determines if in a regression model, some or all of the explanatory variables have a perfect or precise linear relationship. The multicollinearity test determines if the regression model discovered a relationship between the independent variables (independent). The VIF value of each independent variable can be used to test for multicollinearity; if the VIF value is less than 10, the data is free of multicollinearity symptoms. Zero is equal to independent [3].

c) Heteroscedasticity Test

The multi - collinearity test checks if the particles with one data and also the residuals of another observable in the multivariate regression have the same variation [3].

d) Autocorrelation Test

In a straight relapse model, the autocorrelation test is performed to look at in case there is a connection between the bewildering mistake in period $t$ and the puzzling blunder in period t01 (past). An autocorrelation issue happens when there is a connection [3].

\subsection{Multiple Regression Analysis}

Different relapse examination was utilized to decide the impact of the free factor on the reliant variable. There is one ward variable and four autonomous factors in different relapse. Cost to Book Value is the reliant variable (bound) in this review, while institutional possession is the autonomous variable (free). Profit Payout Ratio, Return on Assets, and Return on Equity.

\subsection{Hypothesis testing}

a) T-test (Partial)

According to Ghozali, the halfway test or t test is a test used to decide the impact of every free factor on the reliant variable [3].

b) F-test (simultaneous)

The concurrent test, regularly known as the F test, is a test used to evaluate whether or not the autonomous elements influence the reliant variable at the same time, as per Ghozali [3]. In the F test, with a substantial level of 5\%, the basis for decision-making is Determination Coefficient

Determinant coefficient the reason for testing is to see how much the free factor affects the reliant variable the coefficient of assurance (R2) is a proportion of how adequately a model can clarify varieties in the reliant variable. The coefficient of assurance goes from 0 to 1 . The limit of the free factors to clarify the change of the reliant variable is restricted if the worth 
(R2) is low. A score moving toward one suggests that the autonomous factors give essentially every one of the information needed to estimate the reliant variable's fluctuation [3].

\subsection{Normality Test Results}

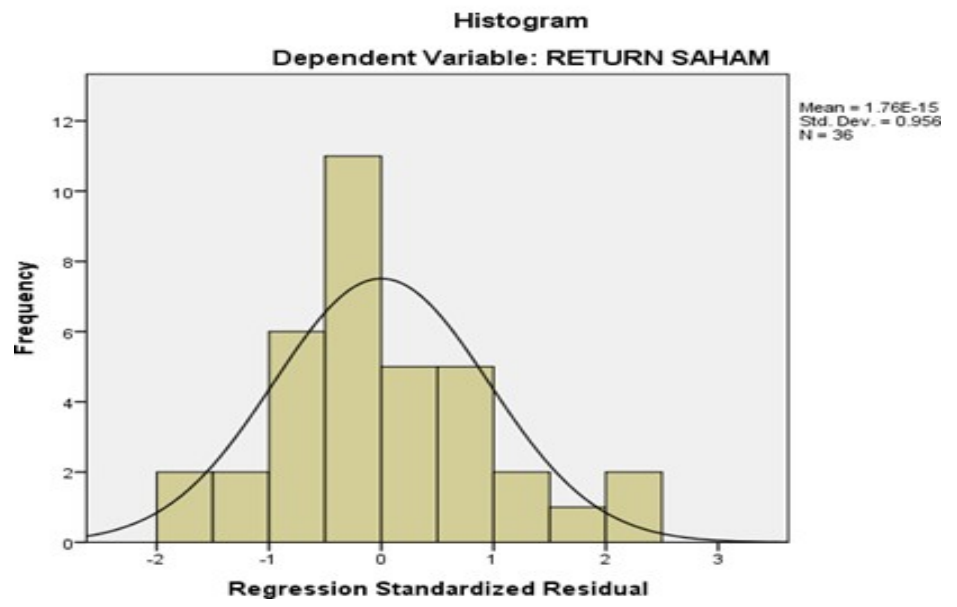

Fig. 1. Histogram graphic

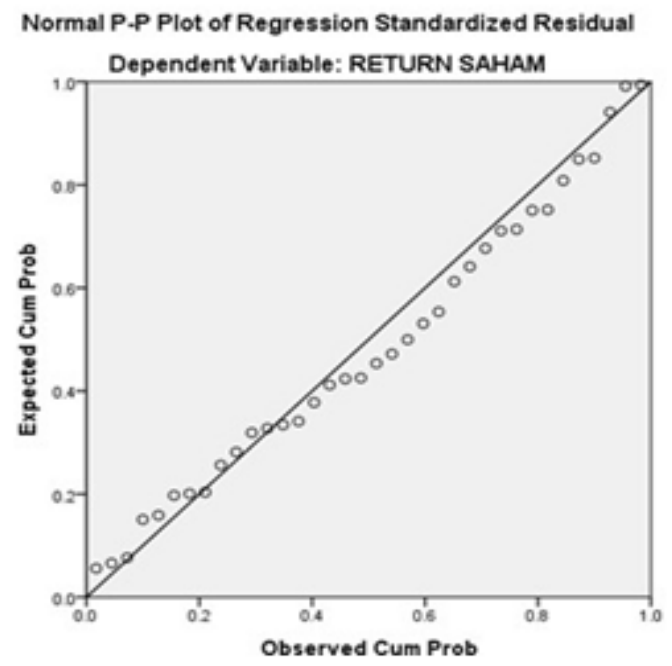

Fig. 2. Histogram graphic

The decision-making criteria in graph 1 analysis explains that the histogram shows that the dependent curve and regression standardized residuals form a bell-like image. The points spread around the diagonal line, as can be seen from the usual look of the normalized p-plot regression. As a result of the normality test, regression analysis is a viable option (fig 2). 


\subsection{Multicollinearity Test Results}

Table 6. Multicollinearity test result

\begin{tabular}{|c|c|c|c|c|c|c|c|c|}
\hline \multicolumn{9}{|c|}{ Coefficients" } \\
\hline \multirow[b]{2}{*}{ Model } & & \multicolumn{2}{|c|}{$\begin{array}{l}\text { Unstandardized } \\
\text { Coefficierts }\end{array}$} & \multirow{2}{*}{$\begin{array}{c}\text { Standardized } \\
\text { Coefficierts } \\
\text { Beta }\end{array}$} & \multirow[b]{2}{*}{$t$} & \multirow[b]{2}{*}{ Sig. } & \multicolumn{2}{|c|}{ Collinearity Statistics } \\
\hline & & B & Std. Error & & & & Tolerance & ViF \\
\hline 1 & (Constant) & 417787.502 & 221726.108 & & 1.884 & .069 & & \\
\hline & INFLASI & -17.120 & 17.143 & -194 & .969 & 365 & 64 & 1.462 \\
\hline & BIRATE & 18.293 & 9030 & .366 & 2026 & .051 & 798 & 1262 \\
\hline & KURS & -32.856 & 14.609 & .443 & 2249 & OSB & ess & 1503 \\
\hline
\end{tabular}

Based on table 6 inflation shows TOL $0.684>0.1$ and VIF $1.462<10$; BI Rate shows TOL $0.792>0.1$ and VIF $1.262<10$; and the exchange rate shows TOL $0.665>0.1$ and VIF $1.503<10$. So, it can be concluded that this study is free from multicollinearity.

\subsection{Autocorrelation Test Results}

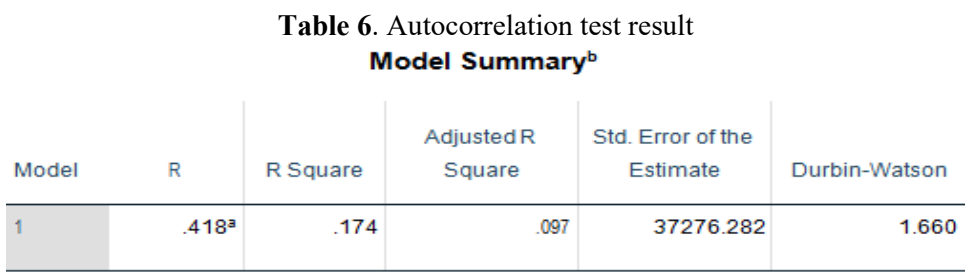

a. Predictors: (Constant), KURS, BI RATE, INFLASI

b. Dependent Variable: RETURN SAHAM

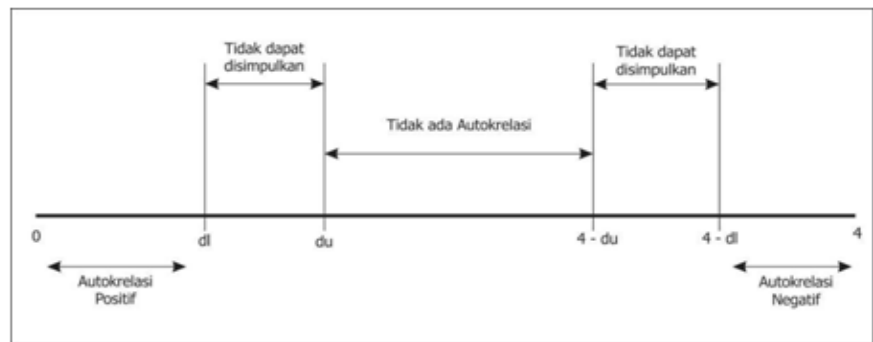

Fig. 3. Multicollinearity test result

Based on Figure 3. the DW value is 1.660 , and in the Durbin Watson table with $=5 \%$. T The values of $\mathrm{dL}=1.2953$ and $\mathrm{dU}=1.6539$ are indicated by (amount of data) $=36$ and $\mathrm{K}$ (number of variables) $=3.4-\mathrm{dL}=4-1.2953=2.70474-\mathrm{dU}=4-1.6539=2.3461$ when calculated the value of 1.660 is found to be between $\mathrm{dU}$ and 4 - dU, i.e., 1.65391 .6602 .3461 , indicating that there is no autocorrelation in this investigation. 


\subsection{Heteroscedasticity Results}

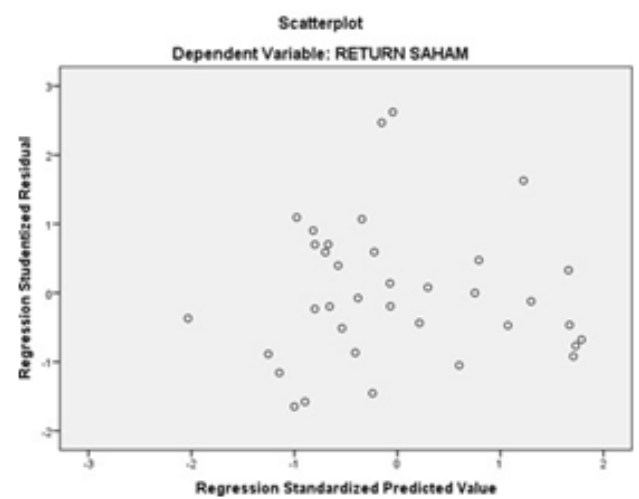

Fig. 4. Heteroskedacities test result

From the focuses are haphazardly circulated above and beneath the number 0 on the $\mathrm{Y}$ pivot, as displayed in the scatterplot picture above. It very well might be reasoned that the relapse model has no heteroscedasticity, and subsequently the relapse model is substantial attainable to use to anticipate stock return factors dependent on expansion input, BI rate, and rupiah swapping scale. It is displayed in figure 4.

\subsection{Multiple Regression Test}

Table 7. Double linear coefficientcy regression test result

\begin{tabular}{|c|c|c|c|c|c|c|}
\hline \multicolumn{7}{|c|}{ Coefficients $^{a}$} \\
\hline \multirow[b]{2}{*}{ Model } & & \multicolumn{2}{|c|}{ Unstandardized Coefficients } & \multirow{2}{*}{$\begin{array}{c}\text { Standardized } \\
\text { Coefficients } \\
\text { Beta }\end{array}$} & \multirow[b]{2}{*}{$\mathrm{T}$} & \multirow[b]{2}{*}{ Sig. } \\
\hline & & $B$ & Std. Error & & & \\
\hline 1 & (Constant) & 417787.502 & 221726.108 & & 1.884 & .069 \\
\hline & INFLASI & -17.120 & 17.143 & -.194 & -.999 & .325 \\
\hline & BI RATE & 18.293 & 9.030 & .366 & 2.026 & .051 \\
\hline & KURS & -32.856 & 14.609 & -.443 & -2.249 & .032 \\
\hline
\end{tabular}

The from the foregoing, a multiple linear regression equation was created calculations, table 7 , is as follows:

$\mathrm{Y}=417787,502-17,120 \mathrm{X} 1+18,293 \mathrm{X} 2-32,856 \mathrm{X} 3$

Where:

$\mathrm{Y}=$ Stock Return

$\mathrm{X} 1=$ Inflation

$\mathrm{X} 2=\mathrm{BI}$ Rate

X3 = Rupiah Exchange Rate 
From the regression equation above, it can be concluded that:

a) Constant (a)

This clarifies that if all free If the worth of the autonomous factors (expansion, BI Rate, and rupiah conversion scale) is 0 (zero), the reliant variable is 417787,502 . This can happen as a result of elements other than expansion, for example, the BI Rate and the rupiah conversion scale, that influence stock returns.

b) Inflation Regression Coefficient

Inflation has a regression coefficient of $-17,120$ and is negative. This explains that inflation has an opposite (negative) relationship with stock returns. This means that as the rate of inflation rises, the price of goods rises as well., while the BI Rate and rupiah exchange rate variables are assumed to be constant, the stock return will experience a change, namely a decrease of $-17,120$ assuming other independent variables are constant.

c) BI Rate Regression Coefficient

The BI Rate has a regression coefficient of 18,293 and is positive. This explains that the BI Rate has a unidirectional (positive) relationship with stock returns. This means that any change in the increase in the BI rate of $1 \%$ will give an increase in share value of 18,293 assuming other independent variables are constant.

d) Rupiah Exchange Rate Regression Coefficient

The rupiah exchange rate has a negative regression coefficient of -32.856 . This explains why the rupiah exchange rate and stock returns have a non-unidirectional (negative) relationship. This means that every unit change in the rupiah exchange rate, while the inflation variable and the interest rate are both changing, the rupiah exchange rate is changing. BI Rate are assumed to be constant, the stock return will experience a change, namely an increase of $-32,856$ assuming other independent variables are constant.

\subsection{Statistical Test Results $t$}

Table 8. Partial t-test results Coefficients $^{\mathrm{a}}$

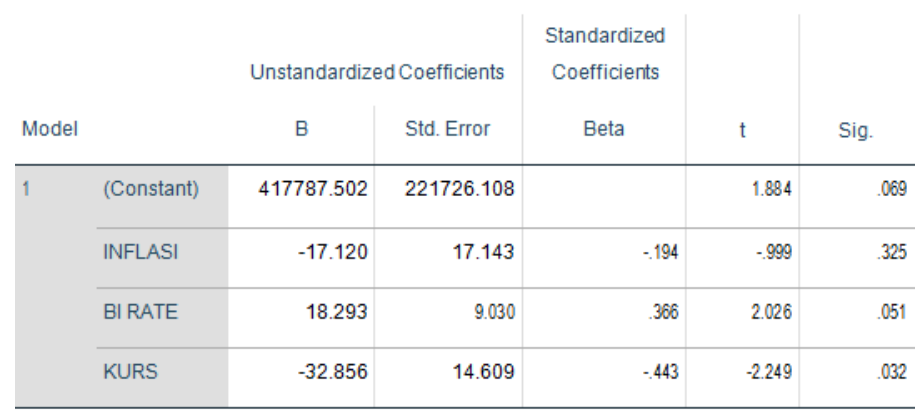

a. Dependent Variable:RETURN SAHAM

The partial t-testing table 8 is indicated by significant values and t-statistics, where these values will partially explain the results of the t-test. Through table 4.6. above, inflation shows a significant value of $0.325>0.05$ which means there is no effect on the dependent variable. Through the calculation of $t$ table shows that $t$ table $(0.025 ; 33)$ is 2.035 , and $t$ count shows the number -0.999 then $-0.999<2.035$, which means there is no effect. Thus, the results of the partial test of inflation have no effect on stock returns. 
The second is the BI Rate. The significant value of the BI Rate shows a significant value of $0.051>0.05$, which means that there is no effect on the dependent variable. By calculating the t table $(0.025 ; 33)$ is 2.0017 and the t-count shows the number 2.026 , then $2.026<2.035$, which means there is no effect. Thus, the results of the partial BI Rate test have no effect on Stock Return. The third is the Rupiah Exchange Rate. The significant value of the Rupiah exchange rate shows a significant value of $0.032<0.05$, which means that there is a significant effect on the dependent variable. By calculating the $t$ table $(0.025 ; 33)$ is 2.035 and the $t$ count shows the number -2.249 then $-2.249<2.035$ which means there is an effect but it is negative. Thus, the results of the partial test of the Rupiah Exchange Rate have a significant effect on Stock Return.

\subsection{F-Test Results (Simultaneous)}

Table 9. The results of the F test

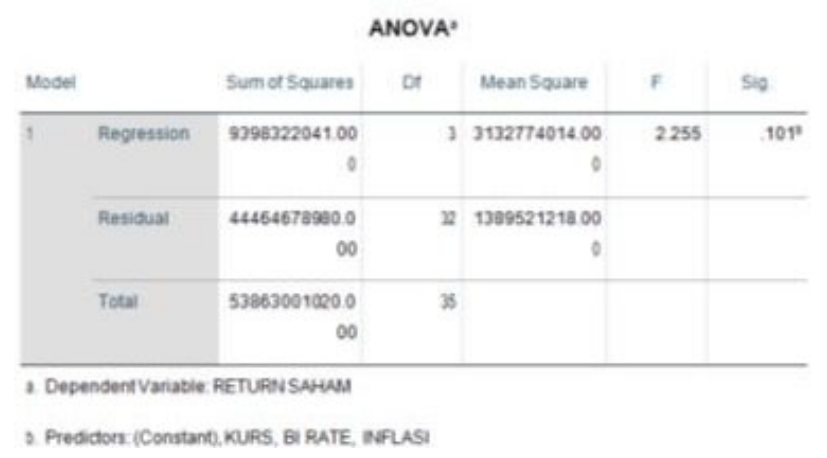

In light of the table 9 of critical levels in this review, the aftereffects of the F test are displayed in the Anova table, which depends on table 4.8. sig esteem shows the number 0.101 $>0.05$ which implies there is no critical impact between Stock returns, expansion, the BI Rate, and the rupiah conversion scale The F esteem in the table is 2.255 , and it is realized that the F table $(3 ; 32)$ is 2.900 , inferring that expansion, the BI Rate, and the rupiah conversion scale have no impact on stock returns. It very well might be gathered that $\mathrm{H} 4$ has no significant impact on stock returns when expansion, the BI Rate, and the rupiah conversion standard are totally estimated at same time.

\subsection{Coefficient of Determination Results}

Table 10. Coefficient of Determination test result

\begin{tabular}{|c|c|c|c|c|c|}
\hline \multicolumn{6}{|c|}{ Model Summary } \\
\hline Model & $\mathrm{R}$ & R Square & $\begin{array}{l}\text { Adjusted R } \\
\text { Square }\end{array}$ & $\begin{array}{l}\text { Std. Error of the } \\
\text { Estimate }\end{array}$ & Durbin-Watson \\
\hline 1 & $.418^{\mathrm{a}}$ & .174 & .097 & 37276.282 & 1.660 \\
\hline
\end{tabular}


Based on the 10 table, the adjusted $\mathrm{R}$ Square value is 0.097 percent $(9.7 \%)$. This demonstrates that inflation, the BI Rate, and the rupiah exchange rate can all explain $9.7 \%$ of the stock returns of property companies. This graph shows how macro inflation indicators, the BI Rate, and the rupiah swapping scale influence stock returns of $9.7 \%$.

\section{Conclusions and Suggestions}

\subsection{Conclusion}

The author has detailed the backdrop of the problem, problem identification, and problem formulation in Chapter I, in accordance with the thesis title, and chapter II discusses the theoretical basis which contains opinions from experts and continues with chapter III on research methods which contains research methods. with populations and samples in data collection with regular research indicator instruments and systematic data analysis methods, so that the authors can provide conclusions on the research results as follows:

a. Inflation has no effect on stock returns in property companies in 2016-2018. This is shown in the results of statistical tests which show that the significant value is 0.325 . This demonstrates that inflation has little impact on stock returns because the economy in Indonesia is currently starting to strengthen and increasing will indirectly affect people's income to invest.

b. The BI Rate has no effect on stock returns in property companies in 2016-2018. This is shown in the results of statistical tests which show that the significant value is 0.051 . The BI Rate has no effect on stock returns because there are some investors who are still waiting to buy shares when the stock price is too high and will buy it when the stock price is very cheap. This is an example that stock returns do not depend on the BI Rate.

c. In the period 2016-2018, the Rupiah Exchange Rate had a major impact on stock returns in property businesses. The significant value for the ui statistic is 0.032 , as seen in the results. The strong or weak exchange rate of the rupiah versus foreign currencies, which is often the source of the rise and fall of stock prices on the stock exchange, has an impact on stock returns.

d. Inflation, the BI Rate, and the Rupiah Exchange Rate all had little effect on property company stock returns in 2016-2018. This is demonstrated by statistical tests, which provide a significant value of 0.101 . This explains why inflation, the BI Rate, also, the rupiah conversion scale all have no impact on stock returns simultaneously since stable stock returns are unaffected by expansion, the BI Rate, and moving rupiah trade rates.

\subsection{Suggestion}

To ensure that the conclusions as stated above are interrelated, the authors hereby provide the following suggestions:

a. For further researchers, it is recommended other macroeconomic factors that affect stock returns, such as economic growth, trading volume, Net Profit Margin, or Gross Domestic Product, because macroeconomic factors in this study are solely confined to inflation, BI Rate, and the rupiah exchange rate. Further researchers can also add a period of time in the study so that the research results are more accurate.

b. For investors, it is recommended that they consider macroeconomic movements other than When considering whether or not to invest in the sector, consider the inflation rate, the BI 
Rate, and the rupiah exchange rate they are interested in. It is also necessary to carry out a strategy in investing.

c. For companies, it is expected to be able to make more company policies to determine the amount of stock prices that pay more attention to aspects Inflation, interest rates, and currency exchange rates are all factors to consider or other macroeconomic factors.

\section{References}

[1] Sugiyono. 2018. Qualitative Quantitative Research Methods and R\&D. Alphabet. Bandung.

[2] Gujarati. (2013). Fundamentals of Econometrics. Jakarta: Salemba Empat.

[3] Ghozali, I. 2016. Application of Multivariate Analysis with IBM SPSS 23 Program. Eighth Edition. Diponegoro University. Semarang. 